\section{Reação da polimerase em cadeia na doença de Chagas crônica: emprego de dois pares de iniciadores TCZ1/ TCZ2 e S35/S36 em isolados de Trypanosoma cruzi de sangue de pacientes e em outros tripanosomatideos}

Considerando as dificuldades existentes para o diagnóstico e controle de tratamento de pacientes na fase crônica da doença de Chagas, constituem objetivos do presente trabalho: 1) Estudar a sensibilidade e especificidade da Reação da polimerase em cadeia (PCR) com dois pares de oligonucleotídeos iniciadores, TCZI/TCZ2, que amplificam uma seqüência repetitiva de 188 pares de bases do DNA genômico do Trypanosoma cruzie S35/S36, que amplificam uma seqüência repetitiva de 330 pares de bases do DNA do cinetoplasto, 2) Verificar a freqüência com que estes iniciadores reconhecem seqüências repetitivas de DNA de amostras de isolados de $T$. cruzi a partir de sangue de pacientes de várias regiões do Brasil. Para estudar a sensibilidade, foram analisados DNA de formas epimastigotas de cepa $Y$ de cultura de T. cruziem diferentes diluições com e sem adição de DNA humano. A presença de seqüências conservadas em amostras de $T$. cruzi foi estudada em 23 isolados a partir de hemocultura e xenodiagnóstico provenientes de sangue de pacientes com doença de Chagas crônica, sem e com co-infecção com o virus da imunodeficiência humana. Visando estudar a especificidade, DNA de diferentes tripanosomatídeos, $T$. rangeli, $T$. brucei, $T$. conorhini, $T$. theileri e $L$. mexicana e $L$. chagasi foram empregados na PCR e em hibridização. Com as PCR realizadas com os iniciadores TCZI/TCZ2 e S35/S36, chegou-se a sensibilidade de até $5 f g$ de $T$. cruzi, equivalente a 0,022 moléculas do parasito, havendo discreta queda na sensibilidade quando adicionado $1 \mu \mathrm{g}$ de DNA humano na amostra a ser amplificada para $10(0,045$ moléculas $)$ e $50 \mathrm{fg}$ (0,22 moléculas), respectivamente. Registrou-se

\section{Polimerase chain reaction in chronic Chagas' disease: use of two pairs of TCZ1/ TCZ2 and S35/S36 primers in isolates of Trypanosoma cruzi of blood from patients and in other trypanosomatids}

In chronic Chagas' disease the difficulty in detecting the parasite Trypanosoma cruzior the parasite antigen both for diagnosis and for followup after treatment constitutes an important problem in medical practice. To address this problem we studied the polimerase chain reaction-based method for the detection of $T$. cruzi product in samples from chagasic patients. We analyzed the sensitivity and specificity of the PCR with two pairs of primers: one pair (TCZI/TCZ2) which amplifies a repetitive sequence of 188 base-pairs from genomic DNA of T. cruzi and another pair (S35/S36) which amplifies a repetitive sequence of 330 base-pairs from kinetoplast DNA of T. cruzi. We studied the efficacy of these primers in detecting $T$. cruzi DNA sequence from T. cruzi isolates obtained from blood samples of patients from different regions of Brazil. Initially DNA of epimastigotes, $Y$ strain was used to study the sensitivity of primers for detection of T. cruziDNA. The sensitivity of the detection with PCR was $5 f g$ with both pairs of primers, which is equivalent to 0.022 parasites DNA molecules. Aslight decrease in sensitivity was observed when $1 \mu \mathrm{g}$ of human DNA was added to the samples, the detection level changing to $10 \mathrm{fg}$ ( 0.045 molecules) with primers TCZI/TCZ2 and to $50 \mathrm{fg}$ (0.22 molecules) with primers S35/S36. The presence of conserved sequences in T. cruzisamples was verified in 23 isolates obtained from hemoculture and xenodiagnosis samples of patients with Chagas' disease, some of them carriers of human immunodeficiency virus. DNA sequences from all isolates obtained from patients was amplified with both pairs of primers, the limit of detection being in the range of 5-50fg. Eighty seven per cent of isolates hybridized using well known TCZP probe

Recebido para publicação em 24/6/99. 
também que ambos iniciadores amplificaram $100 \%$ dos isolados de T. cruzia partir de sangue de pacientes. Observou-se um limiite de detecção de DNA de $T$. cruzi de 5 a $50 f g(0,022$ a 0,22 moléculas do parasito) com três desses isolados. Pode-se observar com a sonda TCZP (Jones et al, 1993) que $87 \%$ dos isolados hibridizaram e com a sonda $\mathrm{Y} 1,78,3 \%$. Com o emprego do produto amplificado da cepa $Y$ como sonda houve hibridização em $100 \%$ dos isolados. No estudo da especificidade, observou-se amplificação de duas cepas de $T$. rangeli $(0,8 \mu \mathrm{g})$ e de $L$. mexicana $(0,4 \mu \mathrm{g})$ e $L$. chagasi $(0,4 \mu \mathrm{g}) \mathrm{com}$ os iniciadores TCZI/TCZ2 e hibridização das mesmas cepas de T. rangeli com a sonda TCZP. Os iniciadores S35/ S36 e a sonda Y1 foram mais específicos não amplificando outros tripanosomas que não o T. cruzi, porém na PCR houve amplificação com DNA de L. mexicana $(0,2$ e $0,4 \mu \mathrm{g})$ e $L$. chagasi $(0,2$ e $0,4 \mu \mathrm{g})$. 0 produto amplificado da cepa $Y$ utilizado como sonda hibridizou com DNA de T. brucei e T. theileri amplificados com S35/S36. 0 estudo demonstrou boa sensibilidade dos pares de iniciadores empregados sem a necessidade de hibridização e reconheceu seqüências dos isolados de pacientes de diversas areas geográficas. Os Iniciadores $\mathrm{TCZI} / \mathrm{TCZ}$ reconhecem seqüências de DNA mais freqüentemente entre os tripanosomatídeos examinados do que S35/S36. and $78,3 \%$ with $\mathrm{Y} 1$ probe. When the amplified product of $Y$ strain was used as probe, $100 \%$ hybridization was noticed with the isolates. To study the specificity, other trypanosomatids of genus Trypanosoma and Leishmania were used. Amplification of DNA sequences from two strains of $T$. rangeli $(0.8 \mathrm{mg})$, Leishmania mexicana $(0.4 \mu \mathrm{g})$ and Leishmania chagasi $(0.4 \mu \mathrm{g})$ was observed using TCZI/TCZ2. The same T. rangeli strains were hybridized with TCZP probe. The primers S35/S36 and probe YI were more specific and no amplification of DNA from other species of Trypanosoma was observed. However, important amplification occurred in PCR with DNA samples from $L$. mexicana $(0.2 / 0.4 \mu \mathrm{g})$ and $L$. chagasi $(0.2 /$ $0.4 \mu \mathrm{g})$. Hybridization with DNA from T. brucei and T. theileri occurred when the amplified product of $Y$ strain was used as probe. We can conclude that both primers in PCR used in this study have good sensitivity to detect sequences of $T$. cruzi. Further hybridization procedure with $T$. cruziderived probes is more expensive and technically more difficult, therefore would be employed only in some restricted cases. These primers recognized sequences present in $T$. cruzi isolates of patients from different regions of Brazil. S35/ S36 primers were more specific to $T$. cruzi than TCZI/TCZ2, which also recognized other trypanosomatids.

\section{Ana Angélica Bulcão Portela Lindoso}

Dissertação apresentada à Faculdade de Medicina da

Universidade de São Paulo para obtenção

do Título de Mestre.

São Paulo, SP, Brasil, 1998 